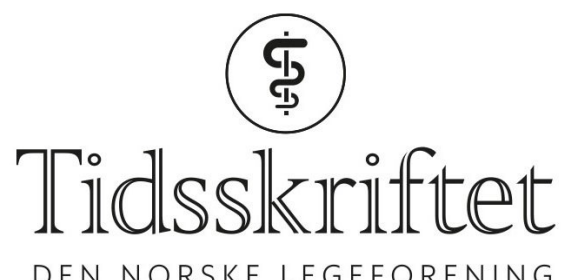

DEN NORSKE LEGEFORENING

\title{
Trenger medisinsk pedagogisk praksis en real overhaling?
}

LEGELIVET

\section{CECILIE BIRKELI}

E-post: cecilie.normann@legeforeningen.no LEFO - Legeforskningsinstituttet

En ny guide gir forslag til hvordan en kan optimalisere læringssituasjonen for studenter i praksis og skape trygge, kompetente klinikere.

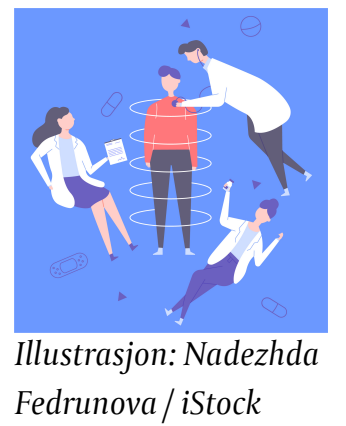

I september startet et nytt kull LIS1-leger i praksis på norske sykehus. I et intervju foretatt av Yngreleger.no forteller et lite utvalg studenter som skal ut i praksis at de har forventninger om en trygg start på arbeidslivet, god veiledning og å få lære av erfarne kolleger (1).

Samtidig skal teoretisk kunnskap omsettes til praksis i møte med pasienter og sykdomsforløp. Her beveger mange studenter seg litt ut av komfortsonen (2).

Disse læringssituasjonene kan utgjøre en fare både for pasientene og legene selv. Men med støtte i et velorganisert læringsmiljø der ekspertene deler sin kunnskap og erfaring, bidrar praksis i vesentlig grad til å skape nye kompetente leger. Har klinikere som veileder disse legene gjennom utdanningsløpet, gode nok pedagogiske verktøy for å skape trygge, kompetente leger?

\section{Hvordan skapes et godt læringsmiljø?}

I en nylig publisert artikkel hevder forfatterne at den konteksten arbeidsarenaen representerer, må tillegges større vekt underveis i utdanningsløpet, fordi opplæring og vurdering av studenter ikke er tilstrekkelig alene til å gjøre dem til dyktige klinikere (2). For å sikre trygge leger som gir god behandling av pasienter, mener derfor forfatterne at det er behov for en real overhaling av medisinsk pedagogisk praksis allerede på medisinstudiet.

For at studenter skal lære å bli gode klinikere, er de nødt til å delta i behandling og få faktisk erfaring med pasienter. De må gis ansvar. Veilederne har en viktig rolle i dette: De må gi av 
seg selv både ved å dele av sine egne erfaringer og støtte studentene ved å involvere dem i samtaler med pasientene om behandling og å gi mulighet til å reflektere over de kliniske erfaringene i etterkant.

Guiden gir også forslag til løsninger som bidrar til trygg, virkelighetsnær læring

Med dette som utgangspunkt har forfatterne utviklet en detaljert guide basert på pedagogisk teori fra erfaringsbasert læring (2). Erfaringsbasert læring er godt forankret empirisk. Dette gjør at teorien passer for ulike land og ulike kontekster, og sannsynligvis også andre helseprofesjoner. Guiden gir råd til klinikere, studenter, ledelse, fakultetsledere og andre utdanningsansvarlige. Den forklarer hvordan medisinstudenter lærer fra praktisk erfaring, foreslår hvordan man kan gå fram for å optimalisere læringssituasjonen og balansere og tilpasse læringen til den enkelte student. For at klinikere skal bli bedre lærere, foreslår guiden å ta i bruk modellen SPaRC. Modellen beskriver prosessene i praktisk læring og ulike egenskaper som medisinstudentene bør tilegne seg for å bli en kompetent lege. Klinikere får råd om hvordan de kan relatere seg til studentene og håndtere dynamikken mellom det å observere og øve på, samtidig som de bidrar i samspillet mellom pasient og student.

\section{Utfordringer og fallgruver}

Det kan være vanskelig å balansere pasientbehandling med opplæring av studenter. Noen pasienter er, av ulike årsaker, ikke villige til å la studenter delta i behandling. Det kan også oppleves utfordrende for studentene å tilpasse seg læringsmiljøet, spesielt når de roterer mellom ulike avdelinger. I guiden foreslås det løsninger til utvikling av avdelingene slik at disse kan bidra til å hjelpe klinikere å gi ekstra støtte i forkant. Dette vil oppmuntre studentene til å ta mer ansvar for egen læring og delta aktivt i praksis (2).

Guiden beskriver viktige prinsipper som gjør det enklere å forstå dynamikken i et læringsmiljø og utfordringer som kan oppstå underveis. Den gir også forslag til løsninger som bidrar til trygg, virkelighetsnær læring.

\section{LITTERATUR:}

1. Haga K. Klar for LIS1. https://yngreleger.no/artikkel/klar-for-lis1. Lest 18.9.2019.

2. Dornan T, Conn R, Monaghan H et al. Experience based learning (ExBL): Clinical teaching for the twenty-first century. https://www.tandfonline.com/doi/full/10.108o/0142159X.2019.163073o Lest 18.9.2019.

Publisert: 7. oktober 2019. Tidsskr Nor Legeforen. DOI: 10.4045/tidsskr.19.0554

(C) Tidsskrift for Den norske legeforening 2020. Lastet ned fra tidsskriftet.no 